\title{
Contact Surveys in Leprosy
}

\author{
P. MOHAMED ALI, M.B.E., M.B.B.s., D.P.H. \\ Head of Division of Epidemiology and Statistics \\ and K. V. N. PRASAD, M.Sc., DIP(STAT), Statistician \\ Central Leprosy Teaching and Research Institute, Chingleput, S. India
}

\section{INTRODUCTION}

A number of factors in the epidemiology of leprosy is still shrouded in mystery. Much work is being done on the subject but the conclusions obtained in some cases are as varied as the pattern of the disease. The Division of Epidemiology and Statistics in the Central Leprosy Teaching and Research Institute Chingleput, South India, initiated a series of studies on certain epidemiological aspects of leprosy and the present survey under report is one among them.

An epidemiological leprosy survey (I96I) covering a population of more than 200,000 distributed over $38 \mathrm{I}$ villages in Chingleput District of Madras State was conducted in a time interval of one year from December 196 I to December 1962, and the results of the survey have already been published $(1963) .{ }^{1}$ The following were the salient features of the survey.

$\begin{array}{lr}\text { Population of the area } & \text { 2 I } 3,72 \text { I } \\ \text { Population examined } & 205,234 \\ \text { Percentage examined } & 96.0 \\ \text { Total cases confirmed } & 4,383\end{array}$

All these 4,383 leprosy patients were distributed in 3,666 families and the number of patients per family ranged from $I$ to 6 . The number of families with more than one patient was 579 and the rest numbering 3087 were single-patient families. There were 14,776 healthy contacts who were living with these patients. All these 4,383 patients and $\mathrm{I} 4,776$ healthy contacts form the population under study. With the object of studying the intra-familial incidence of leprosy contact surveys have been launched in this area covering the above said population. This is a continuous type of survey, the period of observation being one year and already two rounds have been completed. Our object in presenting this report is to review the progress made and to present the results obtained.
2. GOllegtion of DATA: Materials and Method: When the first general survey was carried out the contacts were free from the obvious symptoms of the disease, and the information to be collected was the number of new patients who developed among these healthy contacts during a certain unit of time; and for the sake of calculating the statistical rates this period has been fixed as one year.

All the patients and their contacts were spread throughout an area of 320 square miles. For the administrative convenience and operational facility, the entire area was divided into 20 sectors and a trained paramedical worker posted in each sector. These paramedical workers were primarily meant for the administration of drugs to a certain section of the healthy contacts in the DDS Prophylaxis study which has been going on since 1963 April. All these paramedical workers were trained in the Institute for 6 months in the diagnostic methods of leprosy and they are quite familiar with the local population and in good public relationship with the people under study, which is of vital importance for any survey to be successful. These paramedical workers were utilized in collecting the required information.

The collected information of all the family members is recorded in a family schedule. A copy of the schedule is given in the appendix. ${ }^{1}$

As already mentioned there were 20 paramedical workers and the work load for each paramedical worker ranged from I5O to 200 families.

I 963 January is taken as the starting point and the contact population was surveyed to find the number of new patients only after nearly one and half years and the first round of the contact survey was completed in May, I964 (i.e. after 17 months). From June I 964 , exactly after one year, the population was surveyed for the second time in May, 1965. All the new

Contact Surveys in Leprosy $\quad$ I 73 
patients picked up by the paramedical workers were confirmed or rejected by a Senior Medical Officer of the Epidemiology Division who visited all these reported new patients.

At the time of the general survey there were 4,383 confirmed patients and 14,776 healthy contacts living with them. But at the time of starting the first contact survey, there were 4,4 I5 patients and I 4,275 healthy contacts. The difference in the number of patients (32) is due to the re-examination subsequently of certain suspected new patients. The decrease in the number of healthy contacts is due to leaving out contacts who were not available for examination. Thus in this population we had 4,4 I 5 patients who were considered as the possible sources of infection to their healthy family members. This population is taken up for studying the intrafamilial incidence of leprosy i.e. to know how the disease was spreading in this population who were in contact with the 'source' cases. For this, the population was kept under observation, and the results that are presented here relate to the first contact survey.

\section{RESULTS OF THE FIRST CONTACT SURVEY}

The First Contact Survey showed that 233 new patients occurred during the I 7 months (the period elapsed after the general survey). But for the calculation of the exact period the midpoints of the Survey periods are considered, thus giving us 22 months period during which 233 new patients developed leprosy and for comparing the rates, the results are reduced to a yearly basis.

4. 'SOURGE' SPEGific ATtAGK RATES

All the patients whom we considered as possible 'source' of infection were not of the same type. With a view to understanding the importance of different types of sources in the spread of the disease, all the contacts and new patients who developed leprosy during the first contact survey period are grouped according to the type of source case. (Here only single patient families are considered since there is no way of separating the contacts of the multiple leprosy patient families, the source patients there being of different types. They are however considered separately and presented.)

There were 3, I04 'sources' in single patient families and I 3 I I in multiple patient families; they have respectively 12,198 and 2,077 healthy contacts. All the sources were broadly classified into lepromatous type (L), non-lepromatous type $(\mathrm{N})$, and intermediate type (N ?L). The attack rates according to each type are calculated and given below:

It can be seen that the over-all attack rate irrespective of the type of source is 0.77 . The attack rate in the case of lepromatous type of source is $\mathrm{I} .75$ and 0.49 with intermediate type and 0.69 in the case of non-lepromatous. The attack rate in the case of lepromatous type is statistically significant when compared to the attack rates in the case of the other two types.

The attack rates in the case of non-lepromatous type and intermediate type are not statistically significant from each other suggesting that they are not dangerous to the community to the same extent as far as the spread of infection is concerned.

\section{SOURGE-SPEGIFIC ATTAGK RATES AGGORDING} TO BAGTERIOLOGIGAL INDEX (B.I.)

After noting that the attack rates are different in the case of different types of 'sources', the next thing is to see how the bacteriological status of the source case is important in spreading the infection. For this, all the different types of sources were further classified according to their bacteriological status. Firstly all the types were classified into bacteriological positive, negative, and bacterial index urknown. In the case of non-lepromatous patients only the two classes namely + ye and - ve types are considered and the source patients whose bacteriological index is not known are included in the -ve type. Further all the lepromatous + ve type of sources are classified into different classes according to the degree of the bacteriological index. This helps us to understand whether a high value for bacteriological index has got anything to do with the increased incidence of new patients and thus ipsofacta the attack rate. The respective number of contacts and new patients together with the attack rates are shown in the following table:

By looking at the attack rates, we find that there is a good deal of variation. It can be seen from the table that the number of contacts and new patients in certain categories is too few to draw any valid conclusions regarding the type. In the case of lepromatous type, the attack rates

\section{74 Leprosy Revierw}


with different value of B.I. are different suggesting that the higher the value of the bacteriological index, the higher the attack rate. When the value of the B.I. of the source patient is $I$ to 2 the attack rate is 3.23 which is more than three times the attack rate in the case of sources with B.I. O-I. But in the case of B.I. 2-3, the attack rate is less than when B.I. was $I-2$; it might be due to the small number; and finally in the case of B.I. $3+$, the attack rate is very high. Though it is not possible to draw definite conclusions regarding the potentiality of the 'sources' in spreading infection on the basis of I $\frac{1}{2}$ years observation, it gives us some indication that the grcater the value of the B.I. the greater the risk of infecting the contacts. Because of the unknown long incubation period, we will have to wait for sometime before we draw any justifiable conclusions.

The attack rate in the case of lepromatous + ve type of source is $2 \cdot 96$ and in the case of + ve intermediate type it is $\mathrm{I} \cdot 95$ the difference being statistically not significant. We are not in a position to say anything regarding nonlepromatous + ve type since we have not observed any new patients during the period under observation in this group. We may be in a position to comment on this in subsequent reports.

The attack rates in the case of - ve types of lepromatous, intermediate and non-lepromatous sources are respectively $0 \cdot 60,0 \cdot 49$ and $0 \cdot 69$ which are not statistically different from one another. Thus, broadly we can say that:

(I) among the three types of source patient lepromatous type is more dangerous to the community as far as the spread of the disease is concerned.

(2) when the bacteriological index is considered it is not only lepromatous +ve type but also + ve intermediate type is equally capable of spreading infection.

(3) as far as all —ve source patients are concerned we do not find any difference in the attack rates.

\section{ATTAGK RATES AGGORDING TO NUMBER OF} SOURGES IN THE FAMILY

The next problem is to find out whether multiplicity of source patients in a family has got anything to do with a higher attack rate. For this purpcse all the families were classified into
I, 2, 3, and 4 and above source patients families with their respective contacts and new patients, as shown below.

The attack rate in the case of single patient families is 0.77 and in the case of two-patient; families it is 1.57 which is double the former the difference is statistically significant. The attack rate in the case of three-patient families is I 49 which is sightly less than two patient families-rate, the difference being statistically insignificant. When compared with that of the single patient families, the difference is statistically not significant. The attack rate in the case of 4 patient families is $2 \cdot 63$ which is higher than any one of the above rates but the difference is statistically insignificant. When all the multiple patient families are put together, the attack rate is $\mathrm{I} \cdot 6 \mathrm{o}$ and it is statistically significant when compared to the single source family rate ( $\left.{ }^{\circ} \mathrm{Oo}\right)$. This might be due to the small numbers in the 3 case and $4+$ case families and also the short period of observation.

\section{ATTAGK RATES ACGORDING TO THE SOURGE COMBINATION}

Leaving aside the single-patient families we have 579 multipe patient families. Out of these 579 multiple patient families 465 are two patient families. The contacts of these source patients were further classified according to the type of source combination. When there are two patients in a family they may be (I) both lepromatous type (LL) (2) both non-lepromatous type (NN) and (3) one lepromatous and another non-lepromatous type (IN). In classifying the contacts under these source combinations, the following rule is observed in the case of contacts having $\mathrm{N}$ ? L as one or both sources. Whenever it is bacteriologically positive it is taken as lepromatous type and when negative as nonlepromatous type. We are not in error in doing so since the attack rates as already studied is the same for all negative patients. The following table gives the attack rates in the two patient families according to the type of source combination.

It can be seen that the attack rate when both the sources are lepromatous type is $2^{\circ} 02$. Though we could expect a much higher attack rate in this case, we cannot be dogmatic without some more data, since by a mere increase of one new patient the attack rate will be doubled. 
T AB LE I

Showing the attack rates according to the type of source

\begin{tabular}{lrrrrr}
\hline $\begin{array}{l}\text { Type of } \\
\text { Source }\end{array}$ & $\begin{array}{r}\text { No. of } \\
\text { sources }\end{array}$ & $\begin{array}{c}\text { No. of } \\
\text { contacts }\end{array}$ & $\begin{array}{c}\text { New } \\
\text { patients }\end{array}$ & $\begin{array}{c}\text { Attack } \\
\text { rate }\end{array}$ & $\begin{array}{c}\text { Attack rate } \\
\text { per year }\end{array}$ \\
\hline ' $\mathrm{L}$ ' & 373 ? & I025 & 33 & $3 \cdot 22$ & $\mathrm{I} \cdot 75$ \\
'N' & I65 & 552 & 5 & $0 \cdot 9 \mathrm{I}$ & $0 \cdot 49$ \\
\hline Total & 2566 & I062 I & I 34 & I 25 & $0 \cdot 69$ \\
\hline
\end{tabular}

TABLE 2

Showing the attack rates according to the bacteriological index (B.I.) of the source patient

\begin{tabular}{|c|c|c|c|c|c|c|}
\hline \multicolumn{2}{|c|}{ Type and B.I. } & \multirow{2}{*}{$\begin{array}{c}\begin{array}{c}\text { No. of } \\
\text { sources }\end{array} \\
\text { I } 9\end{array}$} & \multirow{2}{*}{$\begin{array}{r}\begin{array}{c}\text { No. of } \\
\text { contacts }\end{array} \\
56\end{array}$} & \multirow{2}{*}{$\begin{array}{c}\begin{array}{c}\text { No. of } \\
\text { new patients }\end{array} \\
2\end{array}$} & \multirow{2}{*}{$\begin{array}{c}\begin{array}{c}\text { Attack } \\
\text { rate }\end{array} \\
3 \cdot 57\end{array}$} & \multirow{2}{*}{$\begin{array}{c}\begin{array}{c}\text { Attack rate } \\
\text { I year }\end{array} \\
\text { I } \cdot 95\end{array}$} \\
\hline & +ve & & & & & \\
\hline \multirow[t]{3}{*}{ N?L } & -ve & I 05 & 353 & 2 & 0.57 & $0 \cdot 31$ \\
\hline & B.I. unknown & $4 \mathrm{I}$ & I 43 & I & $0 \cdot 70$ & $0 \cdot 38$ \\
\hline & Total & 165 & $55^{2}$ & 5 & $0 \cdot 9^{I}$ & $0 \cdot 49$ \\
\hline \multirow{3}{*}{$\mathrm{L}$} & +ve $\mathrm{O}-\mathrm{I}$ & 43 & I I I & 2 & $\mathrm{I} \cdot 8 \mathrm{o}$ & $0 \cdot 9^{8}$ \\
\hline & I -2 & $5 \mathrm{I}$ & I 52 & 9 & $5 \cdot 9^{2}$ & $3 \cdot 23$ \\
\hline & $2-3$ & 32 & 71 & 3 & $4 \cdot 23$ & $2 \cdot 30$ \\
\hline \multirow{6}{*}{$\mathrm{L}$} & $3+$ & 7 & I 6 & 5 & $3 I \cdot 25$ & I $7 \cdot 04$ \\
\hline & $($ All + ve $)$ & I 33 & $35^{\circ}$ & 19 & $5 \cdot 43$ & $2 \cdot 96$ \\
\hline & -ve & 198 & 544 & 6 & $\mathrm{I} \cdot \mathrm{IO}$ & $0 \cdot 60$ \\
\hline & O.B. & 4 & $\begin{array}{r}344 \\
\text { I } 3\end{array}$ & I & $7 \cdot 69$ & $4 \cdot 20$ \\
\hline & B.I. unknown & $3^{4}$ & I 18 & 7 & $5 \cdot 93$ & $3 \cdot 24$ \\
\hline & Total & 373 & IO25 & 33 & $3 \cdot 22$ & $\mathrm{I} \cdot 76$ \\
\hline \multirow{3}{*}{$\mathrm{N}$} & $+\mathrm{ve}$ & 14 & 40 & o & - & - \\
\hline & -ve & $255^{1}$ & 1058 I & I 34 & $\mathrm{I} \cdot 27$ & $0 \cdot 69$ \\
\hline & Total & 2566 & I 062 I & I 34 & I $\cdot 26$ & $0 \cdot 69$ \\
\hline \multicolumn{2}{|c|}{ Grand Total } & 3104 & 12198 & 172 & $I \cdot 4 I$ & $0 \cdot 77$ \\
\hline
\end{tabular}

TABLE 3

Showing the attack rates according to the No. of sources in the family

\begin{tabular}{lrccc}
\hline $\begin{array}{l}\text { No. of } \\
\text { sources }\end{array}$ & $\begin{array}{c}\text { No. of } \\
\text { contacts }\end{array}$ & New patients & $\begin{array}{c}\text { Attack } \\
\text { rate }\end{array}$ & $\begin{array}{c}\text { Attack rate/ } \\
\text { year }\end{array}$ \\
\hline I source & $\mathrm{I} 2, \mathrm{I} 98$ & $\mathrm{I} 72$ & $\mathrm{I} \cdot 4 \mathrm{I}$ & $0 \cdot 77$ \\
2 sources & $\mathrm{I}, 665$ & 48 & $2 \cdot 88$ & $\mathrm{I} \cdot 57$ \\
3 sources & 329 & 9 & $2 \cdot 74$ & $\mathrm{I} \cdot 49$ \\
4 + sources & 83 & 4 & $4 \cdot 82$ & $2 \cdot 63$ \\
All multiple sources & 2,077 & $6 \mathrm{I}$ & $2 \cdot 94$ & $\mathrm{I} \cdot 6 \mathrm{o}$ \\
\hline Total & $\mathrm{I} 4,275$ & 233 & $\mathrm{I} \cdot 63$ & $0 \cdot 89$ \\
\hline
\end{tabular}


Many of the families are not having contacts at all and their number comes to nearly half. We have to observe these families for some more time before any conclusions are drawn.

When the sources are one lepromatous and one non-lepromatous the attack rate is 3.72 which is higher (3 times) than the attack rate I OI when both sources are non-lepromatous type; the difference is highly significant.

These can be further sub-divided according to the bacteriological status of the source patient, but the figures will become still smaller which will vitiate any justifiable conclusion. For this reason, further analysis has not been attempted.

\section{SEX AND AGE SPECIFIC ATTAGK RATES}

Not only the attack rates by type of source is important, the attack rates by sex and age is also important in understanding the factors responsible for the spread of the disease. All the contacts were grouped by three age groups namely children (O-I 4) adults (I 5-44) and old people (45 and above) according to sex. The following table gives the attack rates by sex and age in the population.

The table shows that the overall attack rates I 04 (children), 0.75 (adults) and 0.86 (old people) are not statistically different from one another, thus suggesting that all are equally capable of contracting the disease. In males it can be seen that the attack rate gradually decreases as the age increases, the old people having the minimum attack rate 0.68 when compared to the attack rate of children $(1 \cdot 26)$ which is almost twice the former. But in the case of females, the picture is different. The attack rate is higher in old people when compared to any other age. But the attack rate in children also is higher than the attack rate in the adults. However the attack rate is lowest in the case of adults ( I 5-44).

When the rates in both the sexes are compared it is seen that the attack rate in adults ( $\mathrm{I}^{\circ} \mathrm{O} 2$ ) in the case of males is statistically different from the attack rate in adults $(0.52)$ in the case of females. But the attack rates in the case of male children $(\mathrm{I} \cdot 26)$ and old males $(0 \cdot 68)$ are not statistically significant when compared to that of female children $(0 \cdot 8 \mathrm{I})$ and old females $(\mathrm{I} \cdot \mathrm{I} 2)$.

It can be seen that the over-all attack rate in males is $\mathrm{I} \cdot 08$ and that of females is 0.72 , the difference being statistically significant suggesting that leprosy attacks males more than females. This difference is mainly reflected in adults since the sex specific attack rates in them are significantly different, while in the old people and children the difference is insignificant.

\section{SEX AND SOURGE-CONTAGT SPEGIFIC ATTAGK RATES}

All the sources and contacts of the single patient families were further classified into different categories namely (a) Male contacts having male sources, (b) Female contacts having male sources, (c) Male contacts having female sources and (d) Female contacts having female sources. All the new patients classified with respect to the above noted categories along with the attack rates and given below.

The attack rate among the contacts having male sources is 0.85 and that of the contacts having female sources is 0.63 the difference is not statistically significant. The attack rates among the male and female contacts having male and female sources are also not statistically significant from each other. But there is a significant difference between the attack rates of the male contacts having male sources ( ${ }^{\circ} \mathrm{O} 5$ ) and the female contacts having female sources (o.52).

It will further be seen from the previous findings that:

(I) the overall attack rate among female contacts is less compared to the attack rate among male contacts, the difference being statistically significant.

(2) the attack rate among the females is minimum in the age group of I 5-44.

(3) the attack rate among the female contacts having female source is least and there is a significant difference when compared to the attack rate among the male contacts having male sources.

These findings suggest some kind of association between the factors governing the transmission of leprosy among the sexes.

To understand clearly the pattern of spread in the population or, in other words, to find whether any particular age group is more vulnerable to the disease, all the contacts were classified into five-year age groups with their 
TABLE 4

Showing the attack rates according to the type of source combination

\begin{tabular}{lcccc}
\hline $\begin{array}{l}\text { Type of } \\
\text { Source }\end{array}$ & $\begin{array}{c}\text { No. of } \\
\text { contacts }\end{array}$ & New patients & Attack rates & $\begin{array}{c}\text { Attack rate } \\
\text { per year }\end{array}$ \\
\hline LL & 27 & $\mathrm{I}$ & $3 \cdot 70$ & $2 \cdot 02$ \\
LN & 337 & 23 & $6 \cdot 82$ & $3 \cdot 72$ \\
NN & I $30 \mathrm{I}$ & 24 & $\mathrm{I} \cdot 84$ & $\mathrm{I} \cdot \mathrm{OI}$ \\
\hline Total & $\mathrm{I} 665$ & & $2 \cdot 88$ & $\mathrm{I} \cdot 57$ \\
\hline
\end{tabular}

TABLE 5

Showing the age and sex specific attack rates

\begin{tabular}{|c|c|c|c|c|c|c|c|c|c|}
\hline \multirow[b]{2}{*}{ Age } & \multicolumn{3}{|c|}{ No. of contacts } & \multicolumn{3}{|c|}{$\mathcal{N}$ ew cases } & \multicolumn{3}{|c|}{ Attack ratelyear } \\
\hline & $M$ & $F$ & All & $M$ & $F$ & All & $M$ & $F$ & All \\
\hline & 3 I I I & 3047 & 6 I 58 & 72 & 45 & I I 7 & $\mathrm{I} \cdot 26$ & $0 \cdot 8 \mathrm{I}$ & $\mathrm{I} \cdot \mathrm{O} 4$ \\
\hline & 2727 & 3224 & $595^{\mathrm{I}}$ & $5 \mathrm{I}$ & $3 \mathrm{I}$ & 82 & $\mathrm{I} \cdot \mathrm{O} 2$ & $0 \cdot 5^{2}$ & $0 \cdot 75$ \\
\hline & I045 & IO2I & 2 I 66 & I3 & $2 \mathrm{I}$ & 34 & $0 \cdot 68$ & $I \cdot 12$ & $0 \cdot 86$ \\
\hline Total & 6883 & $739^{2}$ & 14275 & I 36 & 97 & 233 & $\mathrm{I} \cdot 08$ & 0.72 & $0 \cdot 89$ \\
\hline
\end{tabular}

TABLE 6

Showing the attack rates of different types of contacts

\begin{tabular}{llcccc}
\hline $\begin{array}{l}\text { Type of } \\
\text { sources }\end{array}$ & $\begin{array}{l}\text { Type of } \\
\text { contacts }\end{array}$ & $\begin{array}{c}\text { No. of } \\
\text { contacts }\end{array}$ & $\begin{array}{c}\text { No. of } \\
\text { New patients }\end{array}$ & $\begin{array}{c}\text { Attack } \\
\text { rate }\end{array}$ & $\begin{array}{c}\text { Attack rate/ } \\
\text { year }\end{array}$ \\
\hline a. Male & Male & 3443 & 66 & $\mathrm{I} \cdot 92$ & $\mathrm{I} \cdot 05$ \\
b. Male & Female & 4438 & 56 & $\mathrm{I} \cdot 26$ & $0 \cdot 69$ \\
Total $(\mathrm{a}+\mathrm{b})$ & Male & $788 \mathrm{I}$ & $\mathrm{I} 22$ & $\mathrm{I} \cdot 55$ & $0 \cdot 85$ \\
c. Female & Female & I 52 I & 33 & $\mathrm{I} \cdot 3 \mathrm{I}$ & $0 \cdot 7 \mathrm{I}$ \\
d. Female & & 43 I 7 & $5 \mathrm{I}$ & $\mathrm{I} \cdot 95$ & $0 \cdot 52$ \\
Total $(\mathrm{c}+\mathrm{d})$ & $\mathrm{I}$ 2 I 98 & $\mathrm{I} 72$ & $\mathrm{I} \cdot 4 \mathrm{I}$ & $0 \cdot 77$ \\
\hline Total & & & & \\
\hline
\end{tabular}

respective new patients in both males and females and the attack rates are calculated and shown in the table given above.

It is evident that there is a great deal of variation between the attack rates in different age groups in both between and within sexes. It can also be seen that no particular age is exempt from getting the disease. The age specific attack rates in both the sexes are plotted and shown in the graph overleaf.

The graph show that the attack rate in the case of males steadily increased till the age of I4 and decreased in the next five years. Again in the next five years, it increased to a certain extent and thereafter the increase and decrease occured at intervals of $\mathrm{r} 0$ years.

\section{78 Leprosy Review}




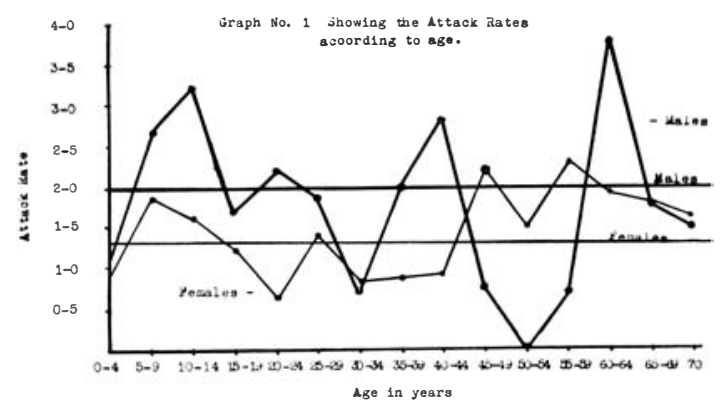

In the case of females, the attack rate increased steadily till the age of 9 years and thereafter gradually decreased till the age of 20 years. In the next five years again the attack rate increased followed by a decrease in the next five years. The attack rate is almost stationary between the ages $30-44$ and thereafter the increase and decrease took place at intervals of five years except the last two age groups. As was observed in the previous paragraphs, the attack rates were least and remained stationary between $3^{0}$ and 44 years. This was seen only in the case of females.

All the contacts for whom the attack rates were calculated are living with different types of 'sources' having different attack rates. The variation which we observed might be due to the different types of sources having different attack rates. To make this point clear all the contacts and new patients were further classified according to the type of source. For this, only three categories were considered, namely, Lepromatous source patients, multiple source patients, and the rest; we have already observed that the attack rates were different in the above categories when compared to the overall attack rates. The following table gives the number of contacts and new patients in the respective age groups according to the type of source patient along with the attack rates.

The age specific attack rates are plotted on a graph in the case of (a) Lepromatous type of source (b) Multiple patient source (c) All the rest, and lastly (d) All sources together. It will be seen that:

(I) The overall attack rate in the case of lepromatous type of source is highest when compared to others.
(2) The attack rate in the case of multiple source patients is also high but slightly less (the difference being statistically not significant (than that of lepromatous type but higher than (c) and (d), the difference being statistically significant.

Even after separating out the different types of sources having different attack rates, still we observe the variation in the age specific attack rates in all the categories namely a, b, c, and $d$. Onc interesting fact we observe from the graph is that the variation is systematic in the sense all the peaks and dips in the different patients occurs almost at the same age level in spite of the different sources having different attack rates. Thus it is clear that the variation is not due to the presence of different types of sources having different attack rates but it is due to some other factor which is operating independently of the source. This has to be investigated further before we draw any inference.

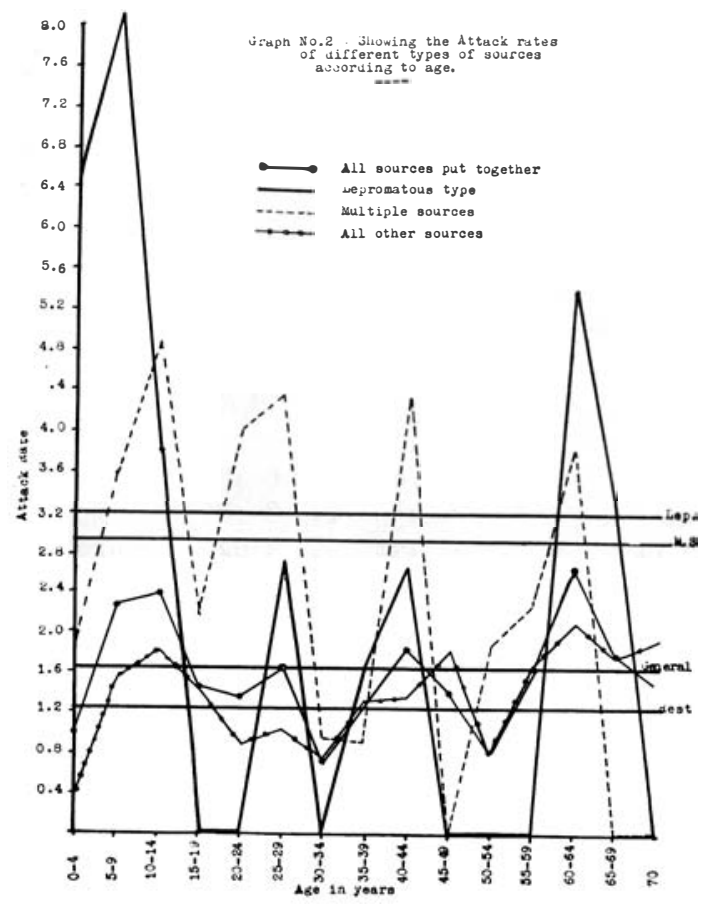

Graph: 2.

Showing the attack rates of different types of sources according to age 
TABLE 7

Showing the age specific attack rates

\begin{tabular}{|c|c|c|c|c|c|c|}
\hline \multirow[b]{2}{*}{ Age } & \multirow{2}{*}{$\begin{array}{c}\text { Male } \\
\text { contacts }\end{array}$} & \multirow[b]{2}{*}{$\mathcal{N}$. cases } & \multirow{2}{*}{$\begin{array}{l}\text { Female } \\
\text { contacts }\end{array}$} & \multirow{2}{*}{$\begin{array}{c}\text { New } \\
\text { patients }\end{array}$} & \multicolumn{2}{|c|}{ Attack rate } \\
\hline & & & & & $M$ & $F$ \\
\hline $0-4$ & 980 & IO & 970 & 9 & $\mathrm{I} \cdot \mathrm{O} 2$ & 0.93 \\
\hline $5^{-9}$ & I I 90 & $3^{2}$ & I I 4 I & $2 \mathrm{I}$ & $2 \cdot 69$ & $I \cdot 84$ \\
\hline $10-14$ & 94 I & 30 & $93^{6}$ & I 5 & $3 \cdot 19$ & $\mathrm{I} \cdot 60$ \\
\hline I $5^{-19}$ & 602 & IO & $49^{8}$ & 6 & I $\cdot 66$ & $\mathrm{I} \cdot 2 \mathrm{O}$ \\
\hline $20-24$ & 632 & I 4 & 714 & 4 & $2 \cdot 22$ & $0 \cdot 56$ \\
\hline $25^{-29}$ & $54^{\circ}$ & IO & 699 & IO & $\mathrm{I} \cdot 85$ & I $\cdot 43$ \\
\hline $30-34$ & 333 & 2 & $5^{10}$ & 4 & $0 \cdot 60$ & $0 \cdot 78$ \\
\hline $3.5-39$ & 301 & 6 & $47 \mathrm{I}$ & 4 & I’99 & $0 \cdot 85$ \\
\hline $40-44$ & 319 & 9 & 332 & 3 & $2 \cdot 82$ & $0 \cdot 90$ \\
\hline $45-49$ & 268 & 2 & 228 & 5 & $0 \cdot 75$ & $2 \cdot 19$ \\
\hline $50-54$ & 224 & o & $27 \mathrm{I}$ & 4 & $0 \cdot 0$ & I $\cdot 48$ \\
\hline $55-59$ & I $3^{8}$ & I & I 73 & 4 & 0.72 & $2 \cdot 3 \mathrm{I}$ \\
\hline $6 o-64$ & I 65 & 6 & 209 & 4 & $3 \cdot 64$ & I $\cdot 9$ I \\
\hline $65-69$ & I 15 & 2 & I I I & 2 & $\mathrm{I} \cdot 74$ & $I \cdot 80$ \\
\hline $70+$ & I 35 & 2 & I 29 & 2 & $\mathrm{I} \cdot 48$ & $\mathrm{I} \cdot 55$ \\
\hline Total & 6883 & I 36 & $739^{2}$ & 97 & I $\cdot 98$ & $I \cdot 3 I$ \\
\hline
\end{tabular}

TABLE 8

Showing the age specific attack rates according to different types of sources

\begin{tabular}{|c|c|c|c|c|c|c|c|c|c|c|c|c|}
\hline \multirow[b]{2}{*}{ Age } & \multicolumn{3}{|c|}{ Lepromatous Type } & \multicolumn{3}{|c|}{ Multiple sources } & \multicolumn{3}{|c|}{ All others } & \multicolumn{3}{|c|}{ Total } \\
\hline & $C$ & N.C. & $A / R$ & $C$ & $\mathcal{N} . G$. & $A / R$ & $C$ & $\mathcal{N} . C$. & $A / R$ & $C$ & $\mathcal{N} . C$. & $A / R$ \\
\hline $0-4$ & I 08 & 7 & $6 \cdot 48$ & 323 & 6 & $\mathrm{I} \cdot 86$ & I 5 I9 & 6 & $0 \cdot 39$ & I950 & I9 & $0 \cdot 97$ \\
\hline $5-9$ & I 59 & 13 & $8 \cdot$ I 8 & 335 & 12 & $3 \cdot 58$ & I 837 & 28 & $\mathrm{I} \cdot 5^{2}$ & 233 I & 53 & $2 \cdot 27$ \\
\hline IO-I 4 & I 3 I & 5 & $3 \cdot 82$ & 267 & I3 & $4 \cdot 87$ & I 479 & 27 & $\mathrm{I} \cdot 83$ & I877 & 45 & $2 \cdot 40$ \\
\hline $15-19$ & 64 & o & o & I 84 & 4 & $2 \cdot 17$ & 852 & 12 & $I \cdot 4 I$ & I IOO & I 6 & I $\cdot 45$ \\
\hline $20-24$ & 93 & o & o & 224 & 9 & $4 \cdot 02$ & I029 & 9 & $0 \cdot 87$ & I 346 & I 8 & $\mathrm{I} \cdot 34$ \\
\hline $25^{-29}$ & I 09 & 3 & $2 \cdot 75$ & I6o & 7 & $4 \cdot 38$ & 970 & IO & $\mathrm{I} \cdot \mathrm{O} 3$ & I 239 & 20 & $I \cdot 6 I$ \\
\hline $30-34$ & 62 & o & o & го6 & I & $0 \cdot 94$ & 675 & 5 & $0 \cdot 74$ & 843 & 6 & $0 \cdot 7 \mathrm{I}$ \\
\hline $35^{-39}$ & $6 \mathrm{I}$ & I & $I \cdot 64$ & 107 & I & $0 \cdot 93$ & 604 & 8 & $\mathrm{I} \cdot 32$ & 772 & IO & $\mathrm{I} \cdot 30$ \\
\hline $40-44$ & 37 & I & $2 \cdot 70$ & $9^{2}$ & 4 & $4 \cdot 35$ & 522 & 7 & $\mathrm{I} \cdot 34$ & $65 \mathrm{I}$ & I 2 & I $\cdot 84$ \\
\hline $45-49$ & 45 & o & o & 71 & o & 0 & $3^{80}$ & 7 & $\mathrm{I} \cdot 84$ & 496 & 7 & $\mathrm{I} \cdot 4 \mathrm{I}$ \\
\hline $50-54$ & 36 & o & o & 54 & I & $\mathrm{I} \cdot 85$ & 405 & 3 & $0 \cdot 74$ & 495 & 4 & $0 \cdot 8 \mathrm{I}$ \\
\hline $55-59$ & 26 & o & $\mathrm{O}$ & 44 & I & $2 \cdot 27$ & $24 \mathrm{I}$ & 4 & I $\cdot 66$ & 3 I I & 5 & $I \cdot 6 I$ \\
\hline $6 o-64$ & 37 & 2 & $5 \cdot 40$ & 52 & 2 & $3 \cdot 85$ & 285 & 6 & $2 \cdot 10$ & 374 & IO & $2 \cdot 67$ \\
\hline $65-69$ & 30 & I & $3 \cdot 33$ & 26 & o & o & I 70 & 3 & $\mathrm{I} \cdot 76$ & 226 & 4 & $\mathrm{I} \cdot 77$ \\
\hline $70+$ & 27 & o & o & 32 & o & $\mathrm{o}$ & 205 & 4 & $\mathbf{I} \cdot 95$ & 264 & 4 & $I \cdot 52$ \\
\hline Total & I 025 & 33 & $3 \cdot 22$ & 2077 & 6 I & $2 \cdot 94$ & I I I 73 & I 39 & I $\cdot 24$ & 14275 & 233 & $\mathrm{I} \cdot 63$ \\
\hline
\end{tabular}

I8o Leprosy Review 
SUMMARY AND GONGLUSIONS

I. Of all types of leprosy, the Lepromatous type has the highest attack rate and is hence more infectious.

2. When the bacterial index is considered, it is not only the lepromatous positive type but $\mathrm{N}$ ? $\mathrm{L}$ positive patients also are equally capable of infecting the contacts.

3. When the bacterial index is negative all the three types whether lepromatous, intermediate or non-lepromatous, the rate of infection is the same and it is less than that of the positive cases.

4. Within the positive lepromatous group, (though it is not quite clear because of insufficient data) it appears that the attack rate increases with the value of the bacterial index.

5. The attack rate in the case of two source families is statistically significant (it is almost double) when compared to the single source family.

6. In the two-patient families, the attack rate is highest when the source combination is lepromatous and non-lepromatous and it is statistically significant when compared to the attack rate when both sources are of non-lepromatous type.

7. In the case of males, the attack rate decreases with the age and in the case of females, the attack rate is lowest in the age group I5-44.

8. The difference in the overall attack rates in the case of males and females are statistically significant.
9. The attack rate is least among the female contacts having females as source cases.

Io. The attack rate among male contacts having males as sources is higher compared to the attack rate among female contacts with males or females as source cases

I I. Age specific attack rates are studied in respect of different types of source patients. The attack rate takes the maximum and minimum values at particular age levels and the variation so observed is rather systematic. No comments are offered on this peculiar phenomenon at present but the matter is being further studied.

\section{AGKNOWLEDGEMENTS}

We wish to express our tharks to the Director, Major-General P. N. Bardhan for permitting us to publish this paper, and to Mr P. Sirumban, Statistical Assistant for his help in the compilation of data.

\section{REFERENGES}

I. mohamed ali, p., An epidemiological Leprosy Survey in Chingleput District of Madras State, (1961). Leprosy in India, I963, 35, I 76-1 87 .

2. Guinto, R. s., Rodriguez, T. N. and Doull, J. A., The trend of Leprosy in Gordova and Talisay, Ciba Province, Philippines, I.J.L., I954, 22, 409-429.

3. WARdekar, R. V., Preliminary report on the data of the control units of the Gandhi Memcrial Leprosy Foundation, I.J.L., I956, 24, I 3-28. 


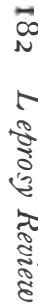

Appendix

Central Leprosy Teaching and Research Institute

Proforma

No. EPID/3/64

\section{Contact Survey Record}

Village:

House No.:

Family No.:

Sector No.:

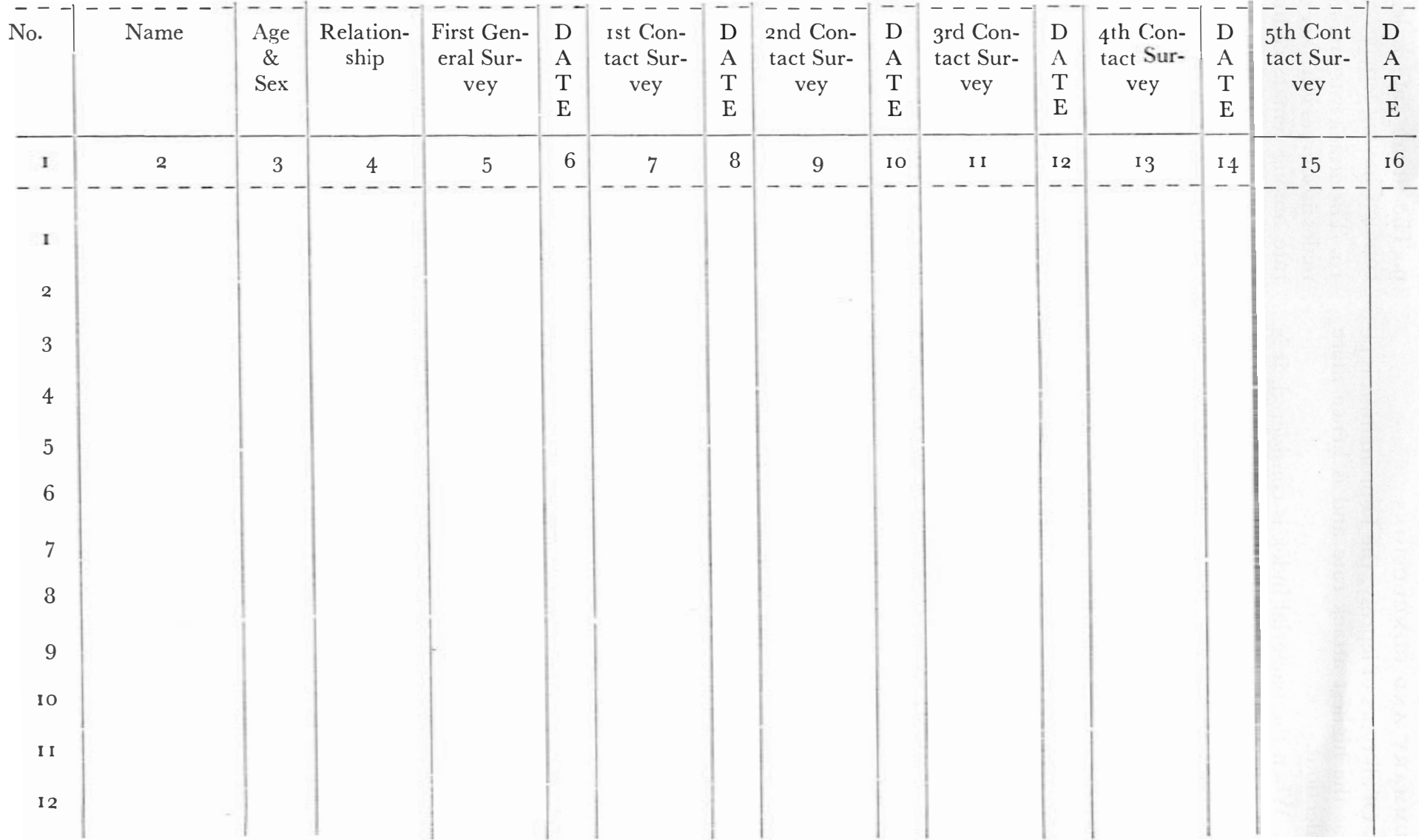

